Dept. of Food Hygiene,

Fac. of Vet. Medicine, Beni-Sueif University.

\title{
MONITORING OF PSYCHROTROPHIC BACTERIA IN MILK AND SOME DAIRY PRODUCTS WITH SPECIAL REFERENCE TO PSEUDOMONAS SPECIES
}

(With 6 Tables)

\author{
By
}

\section{A.M. EL-KHOLY; SAADIA H.E.; G.M. HASSAN and KHADIGA A.H.}

(Received at 9/6/2008)

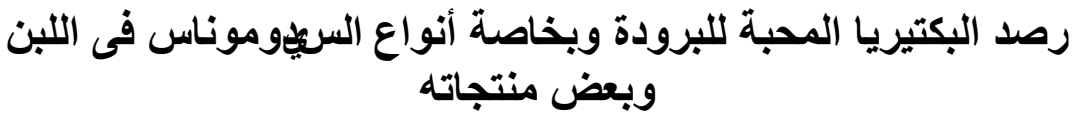

عادل مصطفى الخولمى ، سعدية حلمى الثناوى ، جمال محمد حسن ،

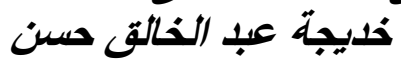

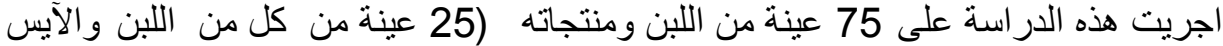

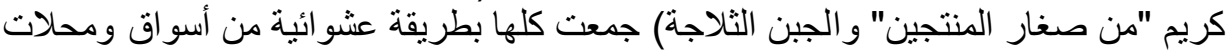

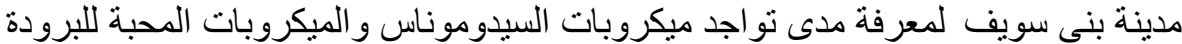

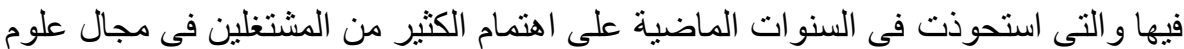

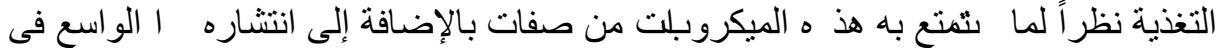

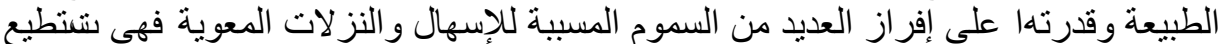

أن نثمو و تثكاثر فى درجات الحرات الحر ارة المنخفضة.

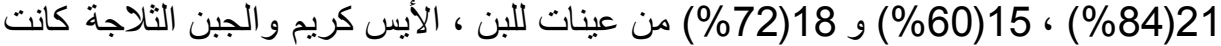

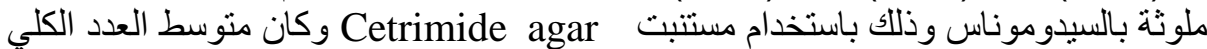



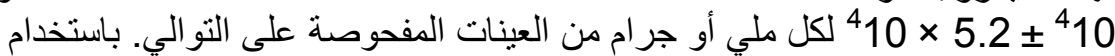


السيدوموناس فى العينات اللبن 1 21(84\%) ، الأيس كريم 16 (64\%) و (64) والجين الثثلاجة

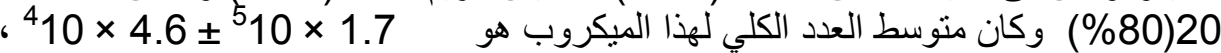
× 2.7

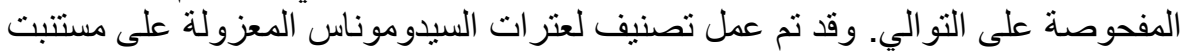
Cetrimide agar

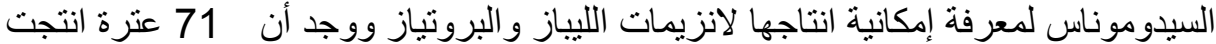

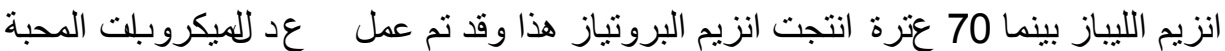


${ }^{6} 10 \times 1.7 \pm{ }^{6} 10 \times 3.5$ ، $510 \times 7.9 \pm{ }^{6} 10 \times 1.95$ ، ${ }^{6} 10 \times 1.9 \pm$ 


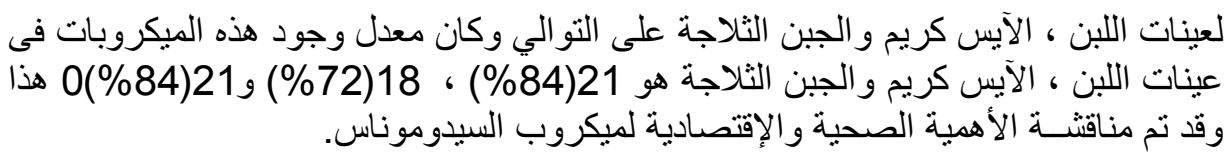

\section{SUMMARY}

Seventy five random samples of milk and some dairy products including raw milk, small scale ice cream and Talaga cheese (each of 25) were collected from different localities in Bani-Suef city. Pseudomonas species could be counted, isolated and identified on cetrimide agar and GSP agar at different counts and percentages, also the incidence and count of psychrotrophic organisms was determined. The characterization of some isolated pseudomonas spp. from the examined samples for the production of extracellular virulence factors as lipolytic and proteolytic enzymes, were detemined and from that 71 pseudomonas spp. showed lipolytic activity while 70 isolates of them showed proteolytic activity. The public health significance of the organism and the precautions, which should be taken to control this organism in the dairy industry as well as the recommended sanitary measures, were also discussed.

Key words: Psychrotrophos, Pseudomonas, Milk, dairy products.

\section{INTRODUCTION}

Milk and dairy products are generally very rich in nutrients which provide an ideal growth environment for many micro-organisms. The microbial quality of raw milk is crucial for the production of good quality dairy products.

Members of the Pseudomonas spp. (Yamamoto et al., 2000) are aerobic gram-negative straight or slightly curved rods, non-spore forming, not-acid fast, non-fermentative bacteria that are widely distributed in nature (Migula, 1894). They are 1 to $5 \mu \mathrm{m}$ long and 0.5 to $1.0 \mu \mathrm{m}$ wide.

It belongs to family Pseudomonadaceae (Pitt, 1998). Some isolates grow under anaerobic conditions by using nitrate as a terminal electron acceptor. They are able to grow over a wide range of temperature $\left(4^{\circ} \mathrm{C}\right.$ to $\left.44^{\circ} \mathrm{C}\right)$, and at neutral or alkaline $\mathrm{PH}$ (7-8.5) but most are not able to grow at PH 6 or below (Holt et al., 1994).

Many species produce characteristic water soluble pigments. The yellow green pigment pyoverdin (Fluorescein) is produced by most Pseudomonas strains, giving the characteristic blue-green appearance 
(Meyer et al., 2002). Ps. aeruginosa can produce the phenazines pyocyanin (blue pigment) and pyorubin (red pigment) (Lau et al., 2004). Rare isolates of Ps. aeruginosa and Ps. cepacia produce the dark brown pigment pyomelanin (Gerald Colle, 1996).

Psychrotrophic bacteria typically enter processed dairy products through post-pasteurization contaminants in the milk processing plants (Moseley, 1980 and Ralyea et al., 1998).

As a result of their metabolic diversity, ability to grow at low temperature and ubiquitous nature, many Pseudomonas spp. can reduce the shelf life of processed milk and cause food spoilage leading to significant economic loss for the food industry. Types of spoilage differ according to the species of Pseudomonas and fat content of milk.

Many strains of Pseudomonas produces heat-stable extracellular lipases, proteases and lecithinases which cause casein digestion leading to a bitter flavor and clotting and gelation of milk or rancid bitter taste and unclean and soapy appearance and many of these enzymes remain active even following thermal processing steps that can destroy the organisms which produce these enzymes (Sorhaug and Stepanik, 1997 and Dogan and Boor, 2003).

Under stressful conditions, these organisms produce an exopolysaccharides that are known as slime layers (biofilm formation). These exopolysaccharides make it difficult to be phagocytosed by mammalian white blood cells (Ryan and Ray, 2004).

Furthermore, Ps. aeruginosa could grow and multiply to numbers sufficient to induce food poisoning (Cheung and Westhoff, 1983).

Several food-borne diarrheal outbreaks linking these organisms were recorded in Yugoslavia (Kenderski, 1974), India (Perena et al., 1977), Canada (Todd, 1981), Bangladesh (Mitra et al., 1993), Taiwan (Wuby et al., 1999) and Nigeria (Nzeako and Okafor, 2002).

In recognition of the economic and public health significance of pseudomonas spp., the present study was planed to fulfill the following:

1 - Enumeration, isolation and identification of Pseudomonas spp. from milk, ice-cream and talaga cheese.

2 - Enumeration of Psychrotrophic bacteria.

3 - Detection of Lipolytic and proteolytic activities of the isolated Pseudomonas species from the different examined samples.

\section{MATERIALS and METHODS}

\section{A- Collection of samples:}


75 samples were randomly collected from different localities including groceries, supermarkets, dairy shops in Bani-Suef city as raw milk, ice-cream and talaga cheese (each of 25). The samples were directly transferred to the laboratory with a minimum time of delay.

\section{B- Preparation of samples and serial dilutions:}

It was performed according to A.P.H.A. (1992).

\section{C- Bacteriological examination:}

1- Enumeration, Isolation and Identification of Pseudomonas organisms (Uroz and Citak, 1998): By using GSP and cetrimide agar plates.

2- Psychrotrophic count (SPC):

It was performed according to A.P.H.A. (1992).

3- Detection of the Lipolytic and proteolytic activities of isolated Pseudomonas spp. from the examined milk and selected dairy products were determined according to Harrigan and McCance. (1976).

\section{RESULTS}

Table 1: Statistical analytical results of the examined Milk, Talaga Cheese and Ice-Cream samples based on pseudomonas count/ $\mathrm{ml}$ or gm on Cetrimide and Gsp agar.

\begin{tabular}{|c|c|c|c|c|c|c|c|}
\hline samples & \multirow{2}{*}{\begin{tabular}{c} 
No. of \\
Examined \\
\cline { 3 - 8 }
\end{tabular}} & \multicolumn{6}{|c|}{ Positive Samples } \\
\cline { 3 - 8 } & Samples & No. & $\%$ & Mean \pm SEM & No. & $\%$ & Mean \pm SEM \\
\hline Milk & 25 & 21 & 84 & $9 \times 10^{4} \pm 3.3 \times 10^{4}$ & 21 & 84 & $1.7 \times 10^{5} \pm 4.6 \times 10^{4}$ \\
\hline $\begin{array}{l}\text { Ice }- \\
\text { Cream }\end{array}$ & 25 & 15 & 60 & $1.2 \times 10^{5} \pm 6.4 \times 10^{4}$ & 16 & 64 & $2.7 \times 10^{5} \pm 1.2 \times 10^{5}$ \\
\hline $\begin{array}{l}\text { Talaga } \\
\text { cheese }\end{array}$ & 25 & 18 & 72 & $7.6 \times 10^{4} \pm 5.2 \times 10^{4}$ & 20 & 80 & $1.1 \times 10^{5} \pm 3.7 \times 10^{4}$ \\
\hline
\end{tabular}

Table 2: Incidence and frequency distribution of the isolated pseudomonas spp. from the examined milk and Ice-cream samples using Cetrimide and Gsp agar.

\begin{tabular}{|c|c|c|c|c|c|c|c|c|c|c|c|c|}
\hline \multirow{3}{*}{$\begin{array}{l}\text { Pseudomonas } \\
\text { spp. }\end{array}$} & \multicolumn{6}{|c|}{ Milk } & \multicolumn{6}{|c|}{ Ice - Cream } \\
\hline & \multicolumn{3}{|c|}{ Cetrimide agar } & \multicolumn{3}{|c|}{ GSP agar } & \multicolumn{3}{|c|}{ Cetrimide agar } & \multicolumn{3}{|c|}{ GSP agar } \\
\hline & No. & Incidence $\% \mathrm{f}$ & frequency & $\mathrm{No}$ & Incidence $\%$ & frequency & $\mathrm{No}$ & Incidence $\% \mathrm{f}$ & frequency & $\mathrm{No}$ & Incidence $\%$ & frequency \\
\hline \begin{tabular}{|l|} 
Ps.aeurginosa \\
\end{tabular} & 3 & 12 & 14.29 & 7 & 28 & 33.33 & 4 & 16 & 26.67 & 6 & 24 & 37.5 \\
\hline \begin{tabular}{|l|} 
Ps.fluorescens \\
\end{tabular} & 8 & 32 & 3 & 4 & 16 & 19.05 & 3 & 12 & 20 & 4 & 16 & 25 \\
\hline Ps. Putida & 4 & 16 & 19.05 & 2 & 8 & 52 & 1 & 4 & 6.67 & 2 & 8 & 12.5 \\
\hline Ps. stu & 2 & 8 & 2 & 4 & 16 & 5 & 4 & 16 & 26.67 & 1 & 4 & 6.25 \\
\hline Ps. 1 & 3 & 12 & 14.28 & 1 & 4 & & 1 & 4 & 6.67 & 2 & 8 & 12.5 \\
\hline Ps. alca & 1 & 4 & 4.76 & 3 & 12 & 14.28 & 2 & 8 & 13.33 & 1 & 4 & 6.25 \\
\hline Total & 21 & 84 & 100 & 21 & 84 & 100 & 15 & 60 & 100 & 16 & 64 & 100 \\
\hline
\end{tabular}


Table 3: Incidence and frequency distribution of the isolated pseudomonas spp. from the examined Talaga cheese samples using Cetrimide and Gsp agar.

\begin{tabular}{|c|c|c|c|c|c|c|}
\hline \multirow{3}{*}{$\begin{array}{c}\text { Pseudomonas } \\
\text { spp. }\end{array}$} & \multicolumn{6}{|c|}{ Talaga cheese } \\
\hline & \multicolumn{3}{|c|}{ Cetrimide agar } & \multicolumn{3}{|c|}{ GSP agar } \\
\hline & No. & Incidence\% & frequency & No. & Incidence $\%$ & frequency \\
\hline Ps.aeurginosa & 2 & 8 & 11.11 & 3 & 12 & 15 \\
\hline Ps.fluorescens & 6 & 24 & 33.33 & 5 & 20 & 25 \\
\hline Ps. putida & 4 & 16 & 22.22 & 2 & 8 & 10 \\
\hline Ps. stutzeri & 3 & 12 & 16.67 & 2 & 8 & 10 \\
\hline Ps.mendocina & 1 & 4 & 5.56 & 4 & 16 & 20 \\
\hline Ps.alcaligenes & 2 & 8 & 11.11 & 4 & 16 & 20 \\
\hline Ps.vesicularis & 0 & 0 & 0 & 0 & 0 & 0 \\
\hline Total & 18 & 72 & 100 & 20 & 80 & 100 \\
\hline
\end{tabular}

Table 4: Lipolytic and proteolytic activities of the isolated pseudomonas spp. from the examined milk and Ice- cream samples.

\begin{tabular}{|c|c|c|c|c|c|c|c|c|c|c|}
\hline \multirow{3}{*}{$\begin{array}{c}\text { Pseudomonas } \\
\text { spp. }\end{array}$} & \multicolumn{5}{|c|}{ milk } & \multicolumn{5}{|c|}{ ice- cream } \\
\hline & \multirow{2}{*}{$\begin{array}{l}\text { No. of } \\
\text { tested } \\
\text { isolates }\end{array}$} & \multicolumn{2}{|c|}{ Lipolytic } & \multicolumn{2}{|c|}{ proteolytic } & \multirow{2}{*}{$\begin{array}{c}\text { No. of } \\
\text { tested } \\
\text { isolates }\end{array}$} & \multicolumn{2}{|c|}{ Lipolytic } & \multicolumn{2}{|c|}{ proteolytic } \\
\hline & & $\begin{array}{c}+ \\
\text { ve } \\
\text { no. }\end{array}$ & $\%$ & $\begin{array}{c}+ \\
\text { ve } \\
\text { no. }\end{array}$ & $\%$ & & $\begin{array}{c}+ \\
\text { ve } \\
\text { no }\end{array}$ & $\%$ & $\begin{array}{c}+ \\
\text { ve } \\
\text { no }\end{array}$ & $\%$ \\
\hline Ps.aeurginosa & 10 & 10 & 100 & 10 & 100 & 10 & 8 & 80 & 10 & 100 \\
\hline Ps.fluorescens & 12 & 10 & 83.33 & 9 & 75 & 7 & 7 & 100 & 5 & 71.43 \\
\hline Ps. Putida & 6 & 4 & 66.67 & 0 & 0 & 3 & 1 & 33.33 & 0 & 0 \\
\hline Ps. Stutzeri & 6 & 3 & 50 & 6 & 100 & 5 & 3 & 60 & 3 & 60 \\
\hline Ps.mendocina & 4 & 1 & 25 & 3 & 75 & 3 & 1 & 33.33 & 1 & 33.33 \\
\hline Ps.alcaligenes & 4 & 0 & 0 & 2 & 50 & 3 & 1 & 33.33 & 0 & 0 \\
\hline Total & 42 & 28 & 66.67 & 30 & 71.43 & 31 & 21 & 67.74 & 19 & 61.29 \\
\hline
\end{tabular}

Table 5: Lipolytic and proteolytic activities of the isolated pseudomonas spp. from the examined Talaga cheese.

\begin{tabular}{|c|c|c|c|c|c|}
\hline \multirow{2}{*}{$\begin{array}{c}\text { Pseudomonas } \\
\text { spp. }\end{array}$} & \multicolumn{5}{|c|}{ Talaga cheese } \\
\cline { 2 - 6 } & $\begin{array}{c}\text { No. of } \\
\text { tested } \\
\text { isolates }\end{array}$ & Lipolytic & \multicolumn{2}{c|}{ proteolytic } \\
\cline { 2 - 6 } & 5 & 4 & 80 & 5 & 100 \\
\hline Ps.aeurginosa & 11 & 9 & 81.81 & 8 & 72.73 \\
\hline Ps.fluorescens & 6 & 5 & 83.33 & - & - \\
\hline Ps. Putida & 6 & - & - & 2 & 40 \\
\hline Ps. Stutzeri & 5 & 1 & 20 & 1 & 20 \\
\hline Ps.mendocina & 5 & 3 & 50 & 5 & 83.33 \\
\hline Ps.alcaligenes & 6 & - & - & - & - \\
\hline Ps. Vesicularis & - & 22 & 57.89 & 21 & 55.26 \\
\hline Total & 38 & & & & \\
\hline
\end{tabular}


Table 6: Statistical analytical results of the examined milk, Talaga cheese and ice-cream samples based on their psychrotrophic count $/ \mathrm{ml}$ or gm by using standard plate count agar (SPC).

\begin{tabular}{|c|c|c|c|c|c|c|c|}
\hline \multirow{2}{*}{$\begin{array}{l}\text { Examined } \\
\text { Samples }\end{array}$} & \multirow{2}{*}{$\begin{array}{c}\text { No. of } \\
\text { examined } \\
\text { Samples }\end{array}$} & \multicolumn{2}{|c|}{$\begin{array}{c}\text { Positive } \\
\text { Samples }\end{array}$} & \multirow{2}{*}{ Min } & Max & Mean & \multirow{2}{*}{ \pm SEM } \\
\cline { 2 - 7 } & No. & $\%$ & & & & \\
\hline Milk & 25 & 21 & 84 & $<10$ & $3 \times 10^{7}$ & $6.7 \times 10^{6}$ & $1.9 \times 10^{6}$ \\
\hline Ice - Cream & 25 & 18 & 72 & $<10$ & $1.58 \times 10^{7}$ & $1.95 \times 10^{6}$ & $7.9 \times 10^{5}$ \\
\hline $\begin{array}{c}\text { Talaga } \\
\text { Cheese }\end{array}$ & 25 & 21 & 84 & $<10$ & $3 \times 10^{7}$ & $3.5 \times 10^{6}$ & $1.7 \times 10^{6}$ \\
\hline
\end{tabular}

\section{DISCUSSION}

\section{Microbiological examination:}

\section{A- Incidence and count of Pseudomonas spp. In the examined samples:}

\section{1- Raw milk:}

The results reported in Table 1 revealed that the pseudomonas species could be detected in $21(84 \%)$ from the examined milk samples with a mean value of $9 \times 10^{4} \pm 3.3 \times 10^{4}$ and $1.7 \times 10^{5} \pm 4.6 \times 10^{4}$, $\mathrm{cfu} / \mathrm{ml}$ on each cetrimide and GSP agar, respectively.

The obtained incidence of pseudomonas species are in agreement to those recorded by Gennari and Dragotto (1992) while lower incidence of pseudomonas species in milk was recorded by Abdel - Khalek and El-Gamal (1998) Aly and Zaki (2001) and Ewida (2005), however, higher incidence were obtained by Ahmed (1995) and Al-Ashmawy et al. (1997).

As shown is Table 2, the isolated of pseudomonas spp. on cetrimide agar could be differentiated into Ps. aeurginosa $12 \%$, Ps. fluorescens $32 \%$, Ps. putida $16 \%$, Ps. stutzeri $8 \%$, Ps. mendocina $12 \%$ and Ps. alcaligenes $4 \%$, while, on GSP agar, the incidence were $28 \%$, $16 \%, 8 \%, 16 \%, 4 \%$ and $12 \%$, respectively. The frequency distribution of different isolates of pseudomonas spp. on cetrimide agar were 14.29, $38.09,19.05,9.52,14.28$ and $4.76 \%$, respectively, while on GSP agar these isolates were detected in frequency percentages of 33.33, 19.05, $9.52,19.05,4.76$ and $14.28 \%$, respectively.

The incidence of Ps. aeurginosa nearly was in harmony with the results recorded by Al-Ashmawy et al. (1992), Khalil (1992) and Aly and Zaki (2001), but was higher than that obtained by Ahmed et al. 
(2002), El-Said (2002), Ahmed and Sotohy (2003) and Ewida (2005). Higher levels were recorded by Zaki et al. (1996), Al-Ashmawy et al. (1997) and Ezzeldeen et al. (2004).

The obtained results of the incidence of Ps. fluorescens was nearly similar to those recorded by Zaki et al. (1996) and El-Said (2002), while higher percentages were recorded by Al-Ashmawy et al. (1997), Sami (1999) and Dogan and Boor (2003), while the lower incidence were reported by Uraz and citak (1998), Ahmed et al. (2002) and Ewida (2005).

In this study it was found that Ps. fluorescens was the predominant bacteria which cause spoilage due to secretion of hydrolytic enzymes such as lipase and protease. Nearly similar findings were reported by Abdel-Hakiem (1996), Dieckelmann et al. (1998), Sobeih (2000) and Dogan and Boor (2003).

The Ps. putida constituted (16\% and $8 \%$ ) on cetrimide and GSP agar, respectively of the examined milk samples. Higher percentage was recorded by Al-Ashmawy et al. (1997) and Aly and Zaki (2001), but lower incidence was obtained by Craven and Macauley (1992), Uraz and Citak (1998) and Ewida (2005).

Ps. aeurginosa is the most important human pathogen in the genus pseudomonas with respect to both the numbers and types of caused infections and their associated morbidity and mortality (Pollack, 1990). Moreover, the presence of Ps. aeurginosa in the intestinal tract of both man and animal and food could be taken as an index of faecal contamination (Hoadley and McCay 1968). The contamination of milk with Ps. aeurginosa may be from the environment of dairy farms such as contaminated water, soil, utensils and faecal matter (Eneroth et al., 1998) and this should be minimized by good manufacturing practices (GMP) at the farm and during production and handling of milk.

Milk are liable to contaminate with pseudomonas organisms during production, handling and processing as well as from animals suffering from mastitis. This organism could grow and multiply to numbers sufficient to induce spoilage of contaminated milk.

Pseudomonas can cause gastroenteritis if ingested in large number $\left(>10^{6}\right)$ but the food could be clearly spoiled by pseudomonas before reaching the limited number (Johnson 1990).

\section{2- Ice-Cream:}

As shown in Table 1 pseudomonas species could be detected in $60 \%$ and $64 \%$ of the examined ice cream samples on cetrimide and GSP 
agar, respectively, with an average count of $1.2 \times 10^{5} \pm 6.4 \times 10^{4}$ and $2.7 \times 10^{5} \pm 1.2 \times 10^{5} \mathrm{cfu} / \mathrm{ml}$, respectively .

Lower incidence were obtained by El-Bassiony et al. (1985), Korashy (1992) and Gomaa (1999).

The incidence of pseudomonas spp. recovered from ice cream samples using cetrimide agar was Ps. aeurginosa 16\%, Ps. fluorescens $12 \%$, Ps. putida $4 \%$, Ps. stutzeri $16 \%$, Ps. mendocina 4\%, and Ps. alcaligenes $8 \%$, while, on GSP agar these organisms were recovered from $24 \%, 16 \%, 8 \%, 4 \%, 8 \%$ and $4 \%$, respectively (Table2). Lower incidence of these isolates was detected by Gomaa (1999).

In the present study Table 3 viewed that the frequency distribution of the isolates were Ps. aeurginosa (26.67 and 37.5), Ps. fluorescens (20 and 25), Ps. putida (6.67and 12.5), Ps. stutzeri (26.67 and 6.25), Ps.mendocina (6.67 and 12.5) and Ps. alcaligenes (13.3 and $6.25)$ on cetrimide and GSP agars, respectively.

Most of these isolates could be isolated from ice cream samples at different percentages by Ahmed (1980), Saad (1983), Grover et al. (1993), Shanker et al. (1994) and Kasana et al. (2002)

Higher pseudomonas count in small vendors ice cream samples may be an index of insufficient heat treatment, improper freezing, contaminated water and using of unclean utensils as well as milker's hands (Otte et al., 1978).

\section{3- Talaga Cheese:}

The obtained results in Table 1 revealed that, 72 and $80 \%$ of examined Talage cheese samples were contaminated with pseudomonas spp. on cetrimide and GSP agars with a mean value of $7.6 \times 10^{4} \pm$ $5.2 \times 10^{4}$ and $1.1 \times 10^{5} \pm 3.7 \times 10^{4} \mathrm{cfu} / \mathrm{gm}$ on both media respectively.

The lower incidence of pseudomonas spp. in cheese was recorded by Desmasure et al. (1995).

The summarized results in Table 3 showed that Ps. aeurginosa could be isolated from $8 \%$ and $12 \%$ of cheese samples, Ps. fluorescens could be isolated from $24 \%$ and $20 \%$ samples; Ps. putida from $16 \%$ and $8 \%$ samples Ps. stutzeri from $12 \%$ and $8 \%$ samples; Ps. mendocina from $4 \%$ and $16 \%$ samples; while Ps. alcaligenes could be detected in $8 \%$ and $16 \%$ samples, respectively by using cetrimide and GSP agar.

Frequency distribution of isolated Ps. spp. from Talage cheese on cetrimide agar Table 3 revealed that $11.11 \%$, 33.33\%, 22.22\%, 16.67\%, $5.56 \%$ and $11.11 \%$ of the isolates were identified as Ps. aeurginosa, Ps. fluorescens, Ps. putida, Ps. stutzeri, Ps. mendocina and 
Ps. alcaligenes, while, on GSP these isolates were detected at percentages of $15,25,10,10,20$ and 20 respectively.

These organisms could be detected at different percentages by El-Bassiony et al. (1985), Kasana et al. (2002), Salmeron et al. (2002) and Leriche et al. (2004).

pseudomonas induce important defects in cheese such as yellow to brown coloration (Leriche et al., 2004) and lead to development of bad ripening flora, flavour and texture defects such as bitterness and running paste (Champagne et al., 1994).

Presence of Ps. organisms in Talage cheese could be attributed to the method of manufacturing, unheat treated milk and bad hygienic measures as well as water used in cheese production (Cantoni et al., 2003). On the other hand, use of pasteurized milk and applying good manufacturing practices are extremely important for production of safe white soft cheese to consumers.

\section{B- Lipolytic and Proteolytic activities of the isolated pseudomonas spp. from milk and dairy products}

\section{1- Raw milk:}

Out of 42 pseudomonas spp. isolates from raw milk samples, 28 $(66.67 \%)$ showed lipolytic activity on tributyrin agar (Table 4), they differentiated into $10(100 \%)$ Ps. aeurginosa, $10 \quad(83.33 \%)$ Ps. fluorescens, 4 (66.67\%) Ps. putida, 3 (50\%) Ps. stutzeri, 1 (25\%) Ps. mendocina, while Ps. alcaligenes couldn't show lipolytic activity.

These results are in agreement with those reported by El-Said (2002) and Ewida (2005). Lower results were obtained by Garg (1990), Jaspe et al. (1995) and Wiedmann et al. (2000), while higher findings were reported by Ahmed (1995) and Al- Ashmawy et al. (1997).

As shown in (Table 4), 30 (71.43\%) isolates from 42 pseudomonas spp. isolates had proteolytic activity and differentiated as follow Ps. aeurginosa 10 (100\%), Ps. fluorescens 9 (75\%), Ps. stutzeri 6(100\%), Ps. mendocina 3(75\%) and Ps. Alcaligenes 2 (50\%).

These results are nearly similar to Al- Ashmawy et al. (1997), El-Said (2002) and Ewida (2005).

\section{2- Ice-Cream:}

Inspection the results in (Table 4) decleared that $21(67.74 \%)$ strains out of 31 isolates from examined ice cream samples showed lipolytic activity by using tributyrin agar. The positive strains of examined pseudomonas for lipolytic activity were, Ps. aeurginosa $8(80 \%)$, Ps. fluorescens $7(100 \%)$, Ps. putida $1(33.33 \%)$, Ps. stutzeri 3(60\%), Ps. mendocina 1(33.33\%) and Ps. alcaligenes 1(33.33\%). On 
the other hand, out of 31 pseudomonas strains from ice cream samples, $19(61.29 \%)$ had proteolytic activity on skim milk agar and a high positive percentages as $100 \%, 71.43 \%$ and $60 \%$ were Ps. aeurginosa, Ps. fluorescens and Ps. stutzeri, respectively followed by Ps. mendocina (33.33\%). While, Ps. putida and Ps. alcaligenes didn't show proteolytic activity.

\section{3- Talaga Cheese:}

Out of 38 pseudomonas spp. isolates from Talaga cheese samples, $22(57.89 \%)$ showed lipolytic activity on tributyrin agar (Table 5), as 4(80\%), 9(81.81\%), 5(83.33), 1(20\%) and 3(50\%) were Ps. aeurginosa, Ps. fluorescens, Ps. putida, Ps. mendocina and Ps. alcaligenes, repectively.

Samples showed proteolytic activity were 21 (55.26\%) from 38 pseudomonas spp. isolates and differentiated as follow 5(100\%), 8(72.73), 2 (40\%), 1(20\%) and 5 (83.33) were Ps. aeurginosa, Ps. fluorescens, Ps. stutzeri, Ps. mendocina and Ps. alcaligenes, respectively.

Many studies have been reported that pseudomonas species are psychrotrophic organisms that can cause spoilage of milk and dairy products as they can produce Lipolytic and proteolytic enzymes which secreted in raw milk during preprocessing stages and survive pasteurization causing reduction in the sensory quality and shelf life of processed fluid milk products (Lopez-Fandino et al., 1993) for example, digestion of casein by proteases can lead to bitter flavor, clotting and gelatin of milk. Lipases hydrolyze tributyrin and milk fat to yield free fatty defects acids, which can produce a range of flavor, described as cheesy, fishy, malty, putrid, soapy and unclean (Cox,1993 and Shah, 1994 ).

\section{C- Incidence of psychrotrophic bacteria in the examined samples: 1- Milk samples:}

The findings reported in (Table 6) indicated that the incidence of psychrotrophic organisms in the examined milk samples was $84 \%$ with a count ranged from $<10$ to $3 \times 10^{7} \mathrm{cfu} / \mathrm{ml}$, and a mean count of $6.7 \times 10^{6} \pm 1.9 \times 10^{6}$

Similar results for psychrotrophic count in milk samples were reported by Prabha et al. (1996) and Kasana et al. (2002), while, lower results were reported by Malik and Mathur (1983), Garg (1990) and So et al. (1992).

\section{2- Ice-Cream:}

The results given in (Table 6) showed that the incidence of psychrotrophic organisms was $72 \%$ with a count ranged from $<10$ to 
$1.58 \times 10^{7} \mathrm{cfu} / \mathrm{ml}$ with a mean value of $1.95 \times 10^{6} \pm 7.9 \times 10^{5} \mathrm{cfu} / \mathrm{ml}$. The obtained results of psychrotrophic organisms are in agreement to those recorded by El-Bassiony et al. (1985), while higher results were recorded by El-Bagoury (1996) and Kasana et al. (2002).

\section{3- Talaga cheese:}

From the obtained results in (Table 6) $84 \%$ of Talaga cheese samples were contaminated with psychrotrophic organisms with a count ranged from $<10$ to $3 \times 10^{7} \mathrm{cfu} / \mathrm{gm}$ with a mean value of $3.5 \times 10^{6} \pm$ 1.7 X $10^{6} \mathrm{cfu} / \mathrm{gm}$. Lower results were reported by Santos et al. (1996) and Kasana et al. (2002).

Although the control of bacterial growth during storage of milk and milk products depends primarily on refrigeration, yet the psychrotrophic bacteria can grow at this low temperature. Longer the refrigerated storage before processing of raw milk, larger chances of spoilage could be caused in milk and dairy products by psychrotrophs (Kasana et al., 2002).

\section{II-Public health significance}

Ps. aeurginosa is an opportunistic human pathogen, most commonly affecting immunocompromised patients such as those with cystic fibrosis, Infection can affect many different parts of the body, but typically targets the respiratory system causing chronic debilitating pulmonary infection due to mucoid variants that are now the major cause of death in patients with cystic fibrosis (Shanson, 1990 and Elkin and Geddes, 2003). Involvement of gastrointestinal tract most commonly occurs in infants and patients with hematologic malignancies and neutropenia that has resulted from chemotherapy and this mostly lead to pseudomonal bacteremia. The spectrum of disease can range from very mild symptoms to severe necrotizing enterocolitis with significant mortality. The infection can cause enteritis, with patients presenting with prostration, headache, fever and diarrhea (Shanghai fever). Young infants may present with irritability, vomiting, diarrhea and dehydration. Ps. aeruginosa is also a common cause of bacterial keratitis, scleral abscess, and endophthalmitis in adults and ophthalmia neonatorum in children. Pseudomonas when introduced produces extracellular enzymes that cause a rapidly progressive and destructive lesion. Also it can cause meningitis and brain abscess. These infections can involve the urinary tract through an ascending infection or through bacteremia spread (Pollack, 1990). 
Pseudomonas typhitis typically present in patients with neutropenia resulting from acute leukemia with a sudden onset of fever, abdominal pain.

Pseudomonas is a common cause of chronic otitis media (Swimmer's ear), patients present with pain, pruritis and ear discharge (Patrick, 1995). Pseudomonas also has emerged as an important source of burn wound sepsis (Holder, 1993). It can also cause endocarditis and infections of bones and joints. Moreover, the organism is responsible for a number of mastitis cases and remains in the udder for a number of years (Howell, 1972).

\section{REFERENCES}

A.P.H.A. (1992): "Standard methods for the examination of dairy products", $16^{\text {th }}$ Ed., American Public Health Association, Washington, D.C.

Abdel-Hakiem, E.H. (1996): "The role of lipolytic psychrotrophic bacteria and their activities in cold stored raw milk", $7^{\text {th }}$ Sci. Cong., Fac. Vet. Med., Assiut Univ., Egypt.

Abd-El-Khalek, A. and El-Gamal, A.M. (1998): "Quality control of pasteurized milk sold at Mansoura city in Egypt", Benha Vet. Med. J., 9 (1), 70-79.

Ahmed, A.K.S. (1995): "Assessment of Pseudomonas in farm bulk milk", PhD Thesis, Fac. Vet. Med., Zagazig Univ., Egypt.

Ahmed, H.F.; Ismail, A.M. and Tonios, A.I. (2002): "Occurance of Pseudomonas in raw cow's milk, and trials to control Ps. aeruginosa in butter and Tallaga cheese", Vet. Med. J., 50 (4), 589-599.

Ahmed, M.M. and Sotohy, S.A. (2003): "Sanitary conditions of milking environment in Assiut dairy farms and the quality of their produced milk", Assiut Vet. Med. J., 49 (97), 88-112.

Ahmed, S.H. (1980): Studies on acute gastrointestinal infection in Assiut Governorate. Ph. D. thesis, Assiut University.

Al-Ashmawy, A.M.; El-Gamal, A.M. and Abd-El-Khalek, A. (1997): "Prevalence of Pseudomonas in farm bulk milk", Assiut Vet. Med. J., 36 (2), 215-221.

Al-Ashmawy, A.M.; El-Sherbini, M. and El-Sayed, M.S. (1992): "Prevalence of Ps. aeruginosa and Ps. fluorescens in farm milk", Zagazig Vet. J., 20 (3), 383-388. 
Aly, Salwa and Zaki, Hoda (2001): "Studies on Pseudomonas species in milk and feces of dairy cattle", Assiut Vet. Med. J., 46 (2), 172-186.

Cantoni, C.; Stella, S.; Cozzi, M.; Iacumin, L. and Comi, G. (2003): Blue colouring of Mozzarella cheese. Industrie Alimentari., 42 (428): $840-843$.

Champagne, C.; Laing, R.; Roy, D.; Mafu, A. and Griffiths, M. (1994): "Psychrotrophs in dairy products; effect and control", Crit. Rev. Food SCi. Nutr., 34 (1), 1-30.

Cheung, B.A. and Westhoff, D.C. (1983): "Isolation and identification of ropy bacteria in raw milk", J. Dairy Sci., 66 (9), 1825-1834.

Cox, J.M. (1993): "The significance of psychrotrophic pseudomonas in dairy products", Aust. J. Dairy Technol., 48, 108-113.

Craven, H.M. and Macauley, B.J. (1992): "Psychrotrophic microorganisms in refrigerated pasteurized milk", Brief Communication of the XXIIII International Dairy Congress, Montreal, Vol. 1, 8-12.

Desmasures, N.; Radiguet, S.; Lejeune, J.; and Gueguen, M. (1995): "Effect of ripening on the microbiological profile of high quality raw milk for cheese making", Milchwissenschaft, 50 (4), 193-195.

Dieckelmann, M.; Johnson, L.A. and Beacham, I.R. (1998): "The diversity of lipases from psychrotrophic strains of Pseudomonas; a novel lipase from a highly lipolytic strains of Ps. fluorescens", J. Appl. Microbiol., 85, 527-536.

Dogan, B. and Boor, K.J. (2003): "Genetic diversity and spoilage potentials among Pseudomonas spp. isolated from fluid milk products and dairy processing plants", Appl. Environ. Microbiol., 69 (1), 130-138.

El-Bagoury, A.M. (1996): Bacteriological quality of market ice cream. Vet. Med. J., Giza. Vol 44 (2): 203 - 207.

El-Bassiony, T.A.; Aboul-Khier, F. and Saad, N.M. (1985): Psychrotrophic bacteria in dairy products. Assiut Vet. Med. J., Vol 15 (29): 101-105.

Elkin, S. and Geddes, D. (2003): "Pseudomonal infection in cystic fibrosis", Expert. Review of Anti-infection Therapy, 1 (4): 611-615.

El-Said, E.I. (2002): "Studies on food poisoning bacteria with special reference to Campylobacter jejuni in milk", PhD Thesis, Fac. Vet. Med., Zagazig Univ., Egypt. 
Eneroth, A.; Christiansson, A.; Brendehaug, J. and Molin, G. (1998): "Critical contamination sites in the production line of pasteurized milk with reference to the psychrotrophic spoilage flora", Int. Dairy J., 8 (9): 829-834.

Ewida-Rania, M.M.A. (2005): Survey of the pseudomonas bacteria in milk sold in Assiut city. M.V.Sc. These, Fac. Vet. Med., Assiut Univ. Egypt.

Ezzeldeen, Nashwa, A.; Abdel-Fattah, S.H. and Soliman, Y.A. (2004): "Phenotypic and molecular characterization of Ps. aeruginosa of animals and human origins", J. Egypt. Vet. Med. Assoc., 64 (1): 93-104.

Garg, S.K. (1990): "Psychrotrophs in milk", A review, Ind. J. Dairy Sci., 43 (3), 278-284.

Gennari, M. and Dragotto, F. (1992): "A study of the incidence of different fluorescent Pseudomonas species and biovars in the microflora of fresh and spoiled meat, fish, raw milk, cheese, soil and water", J. Appl. Bacteriol., 72 (4): 281-288.

Gerald Collee (1996): Practical Medical Microbiology. $4^{\text {th }}$ Ed. Pp: 413.

Gomaa-Maha, M. (1999): Studies on the proteolytic psychrotrophic bacteria in ice cream. B.V.S. Thesis, Fac. Vet. Med., Zagazig Univ., Egypt.

Grover, S.; Batish, V.K. and Srinivasan, R.A. (1993): Growth proteolytic and enterotoxic activities of pseudomonas aeurginosa CTM-3 in milk, ice cream and butter. Archive. Fur. Lebensmittel Hygiene 44 (5): 115-117.

Harrigan, W.E. and McCance, M.F. (1976): "Laboratory methods in food and dairy microbiology", Academic press, London.

Hoadley, A.W. and McCay, E. (1968): Some observation on the ecology of pseudomonas aeurginosa and its occurance in the intestinal tracts of animals. Corne II vet., 58: 345-363.

Holder, I.A. (1993): "Ps. aeruginosa virulence associated factors and their role in burn wound infection", R.B. Ficks, Jr (Ed.); Ps. aeruginosa; the opportunistic, CRC press, Boca Roton, 235-245.

Holt, J.G.; Krieg, N.R.; Sneath, P.H.A.; Staley, J.T. and Williams, S.T. (1994): "Berges's Manual of Determinative Bacteriology", $9^{\text {th }}$ Ed., Washington, D.C.

Howell, D. (1972): Survey on mastitis caused by environmental bacteria. Vet. Rec., 90: 554-557. 
Jaspe, A.; Oviedo, P.; Fernaudez, L.; Palacios, P. and Sanjose, C. (1995): "Cooling raw milk: changes in the spoilage potential of contaminating Pseudomonas", J. Food Prot., 58 (8): 915-921.

Johnson, E.A. (1990): In food borne diseases. Ed. Cliver D.O., Academic press Limited, London.

Kasana, R.C.; Punj, V. and Matta, H. (2002): "Isolation and identification of gram-negative lipase producing psychrotrophic bacteria from some dairy products", Ind. J. Dairy Sci., 55 (1): 13-16.

Kenderski, S. (1974): "Cases of food poisoning in Yugoslavia", Flieschwirtschaft, 54 (5): 931-933.

Khalil, Nawal (1992): "Occurance, detection and significance of Ps. aeruginosa in raw milk", Assiut Vet, Med. J., 28 (2): 152-157.

Korashy, Eman, A. (1992): "Incidence of Ps. aeruginosa in milk and some milk products", M.V.Sc. Thesis, Fac.of Vet. Med., Assuit Univ., Egypt.

Lau, G.W.; Hassett, D.J.; Ran, H. and Kong, F. (2004): "The role of pyocyanin in Ps. aeruginosa infection", Trends in Molecular Medicine, 10 (2): 599-606.

Leriche, F.; Bordessules, A.; Fayolle, K.; Karoui, R.; Laval, K.; Leblanc, L. and Dufour, E. (2004): "Alteration of raw milk cheese by Pseudomonas spp.", J. Microbiol. Methods, 59 (1): 33-41.

Lopez-Fandino, R.; Olano, A.; Corzo, N. and Romos, M. (1993): "Proteolysis during storage of UHT milk; differences between whole and skim milk", J. Dairy Res., 60, 339-347.

Malik, R.K. and Mathur, D.K. (1983): Isolation and identification of protease producing psychrotrophic bacteria from dairy products in India. J. Soc. Dairy Technol. 36: 76-78.

Meyer, J.M.; Geoffrey, V.A. and Baida, N. (2002): "Siderophore typing, a powerful tool for the identification of fluorescent and non fluorescent Pseudomonas", Appl. Environ. Microbiol., 68 (6): 2745-2753.

Migula, W. (1894): Ube rein neues system der bakterien, Arbeiten aus dem bakteriologischen Institut der Technischen, 1, 235-238.

Mitra, A.K.; Albert, A.J. and Alam, A.N. (1993): Bacteraemia and meningitis among haospital patients with diarrhea. Trans. R. Soc. Trop. Med. Hyg., 87 (5): 560-563.

Moseley, W.K. (1980): "Pin pointing post pasteurization contamination", J. Food Prot., 43, 414-415. 
Nzeako, B. and Okafor, N. (2002): Bacterial enteropathogens and factors associated with seasonal episodes of gastroenteritis in Nsukka, Nigeria. Br. J. Biomed. Sci., 59 (2): 76-79.

Otte, I.; Hahn, G. and Tollin, A. (1978): Detection, incidence and significance of pseudomonas aeurginosa in raw milk and the environment of dairy plants. Dairy Sci. Abst. 40 (9).

Patrick, R.M. (1995): "Manual of clinical microbiology", 6 ${ }^{\text {th }}$ Ed., ASU press, Washington, D.C., chapter 3.

Perena, S.; Mathan, M.; Bhat, P.; Albert, M.J. and Baket, J. (1977): "Etiology of acute gastroenteritis in fancy and early childhood in southern India", Arch. Dis. Child., 52 (6): 482-485.

Pitt, T.L. (1998): "Pseudomonas, Burkholderia and related genera", Topley and Wilson's Microbiology and Microbial Infections", $9^{\text {th }}$ Ed., Oxford Univ. Press, New York, chapter 47.

Pollack, M. (1990): "Principles and practice of infectious diseases", $3^{\text {rd }}$ Ed., Churchill Livingstine, New York.

Prabha, R.; Krishna, R. and Shanker, P.A. (1996): "Identification of gram-negative rod shaped psychrotrophic bacteria of dairy origin", Ind. J. Dairy Sci., 49 (8): 517-518.

Ralyea, R.D.; Wiedmann, M. and Boor, K.J. (1998): "Practical tracking in a dairy production system using phenotypic and ribotypic methods", J. Food Prot., 61, 1336-1340.

Ryan, K.J. and Ray, C.G. (2004): "Sherris Medical Microbiology", $4^{\text {th }}$ Ed., MC Graw Hill, ISBN.

Saad, Nagah, M. (1983): Psychrotrophic bacteria in milk and milk product. M.V.Sc. Thesis, faculty of vet. Med., Assiut university Egypt.

Salmeron, J.; Devega, C.; Perez-Elortondo, F.J.; Albisu, M. and Barron, L.J.P. (2002): Effect of pasteurization and seasonal variations in the microflora of ewe's milk for cheese making (19): 167-174.

Sami, Enas, M. (1999): "Prevalence of Aeromonas spp. in milk and some milk products in sharkia Governorate", M.V.Sc. Thesis, Fac. Vet. Med., Zagazig Univ., Egypt.

Santos, J.A.; Lopez, Diaz, T.M.; Garcia-Fernandez, M.C.; GarciaLopez, M.L. and Otero, A. (1996): Characterization and extracellular activity of Psychrotrophic bacteria isolated from villalon cheese (Fresh variety of Spanish sheep's milk cheese). International journal of food Microbiology., 33 (2): 301-306. 
Shah, N.P. (1994): "Psychrotrophs in milk", A review, Milchwissenschaft, 49 (8): 432-437.

Shanker, K.; Narasimhan, R. and Khan, M.M.H. (1994): Incidence, isolation and characterization of psychrotrophs in ice cream. Indian Vet. J., 71 (12): 1202-1206.

Shanson, D.C. (1990): "Septicaemia in patients with AIDS", Trans. R. Soc. Trop. Med. Hyg., 84, 14-16.

So, M.H.; Yoon, S.S. and Kim, Y.B. (1992): "Psychrotrophic microflora in raw milk and their proteolytic and lipolytic ability", Korean J. Dairy Sci., 14 (1): 43-51.

Sobeih, Azza, M. (2000): "Studies of raw milk quality in Kafr El-Sheikh", PhD Thesis, Fac. Vet. Med., Tanta Univ. (Kafr El-Sheikh Branch), Egypt.

Sorhaug, T. and Stepanik, L. (1997): "Psychrotrophs and their enzymes in milk and dairy products; quality aspects", Trends Food Sci. Technol., 8, 35 - 40.

Todd, E.C.D. (1981): "Food borne and water borne diseases in Canada", J. Food Prot., 44, 787-795.

Uraz, G. and Citak, S. (1998): The isolated of pseudomonas and other Gram (-) psychrotrophic bacteria in raw milk. J. Basic Microbiol., 38 (2): 129-134.

Wiedmann, M.; Weilmier, D.; Dneen, S.S.; Ralyea, R. and Boor, K.J. (2000): "Molecular and phenotypic characterization of Pseudomonas spp. isolated from milk", Appl. Environ. Microbiol., 66 (5): 2085-2095.

Wuby, P.C.T.; Tsai, C.H. and Chiu, H.H. (1999): Community-acquired Ps. aeurginosa bacteramia and sepsis in previously healthy infants. J. Acta paediat., Taiwan, 40 (4): 233-236.

Yamamoto, S.; Kasai, H.; Arndd, D.L.; Jaskson, R.W. and Harayama, S. (2000): "Phylogeny of the genus Pseudomonas; intrageneric structure reconstructed from the nucleotide sequences of gyrB and proD genes", Microbiol., 146, 2385-2394.

Zaki, M.S.A.; Abd-El-Khalek, A. and Mowafy, L.E. (1996): "Hygienic importance of Pseudomonas in dairy farms", $7^{\text {th }}$ Sci. Cong., Fac. Vet. Med., Assuit Univ., Egypt. 